\title{
Work-related Musculoskeletal Pain and Health-related Quality of Life among Physical Therapists in Korea
}

\author{
Giwon Kim¹, Kyunghee Lee ${ }^{2}$ \\ 'Department of Physical Therapy, College of Health Science, Korea University, Research Institute of Health Sciences, Korea University, Seoul; \\ 2Department of Physical Therapy, Dong Nam Health University, Suwon, Korea
}

Purpose: Physical therapists are likely to be exposed to work-related musculoskeletal pain due to excessive repetitive tasks. This study was conducted to identify the relationship between work-related musculoskeletal pain and quality of life of physical therapists.

Methods: A self-reported questionnaires was sent to 200 physical therapists at in Seoul and Kyoungido. The questionnaires was returned by 170 physical therapists. The questionnaire had included 4 items that coveringed demographic information, areas of musculoskeletal problems, pain rating scale, and WHOOOL-BREF. The analysis was completed using descriptive statistics, and differences between pain and demographic variables were identified using the chi-square test. The relationship between work-related musculoskeletal pain and quality of life was analyzed by t-test and Pearson's correlation.

Results: The overall prevalence of work-related musculoskeletal pain was $76.8 \%$. The most affected pain sites included the low back $(48.8 \%)$, shoulder (45.,2\%), hand and wrist (43.5\%), and neck (33.3\%). Pain ratings of subjects with pain was were moderate. There was a A significant difference for the subdomains of quality of life was observed between the subjects with musculoskeletal pain and those without pain. Weak negative correlations $(r=-0.28)$ were observed between pain rating scale and QOL.

Conclusion: These findings show that physical therapists appear to be at a higher risk for work-related musculoskeletal pain and physical domain of QOL. Therefore, Ffurther research is needed to investigate examine the effect of risk factors and ergonomics as physical load, general health status on prevalence of musculoskeletal pain.

Keywords: Work-related musculoskeletal pain, Quality of life, Physical therapist

\section{서 론}

근골격계 질환은 국가별로 공식적인 발생율과 유병률을 산출하기는 매우 어렵다. 하지만 여러 나라에서 근골격계 질환을 직업과 관련한 질병의 범주로 분류하고 있으며 상당한 비용과 함께 삶의 질에 영향 을 미치는 것으로 알려져 있다. 작업관련성 근골격계 질환(Work-related musculoskeletal disorders, WMSD)은 반복적이고 지속적인 동작 이나 자세와 관련한 반복 작업으로 인해 신체 여러 부위의 근육, 힘 줄, 신경 등에 발생하는 통증을 동반한 질환으로 정의하며, 현대 노동 자들의 만성 통증과 신체 장애의 가장 대표적인 원인이기도 하다.-4

작업과 관련된 근골격계 통증은 일상적인 불편함 정도로 여겨 대 수롭지 않게 생각하는 경향이 있으며 직장에서도 개인적인 문제로 간주해 통증으로 인한 업무 결손에 부정적인 생각을 가지고 있는 것 이 사실이다.5,6 그러나 근골격계 질환은 한번 발병하게 되면 만성화
되는 질환이며 완전히 회복하는데 많은 시간이 필요하고 그 기간에 작업 손실 등 경제적인 손실도 적지 않으므로 지속적 관리에 의해 질 환 발생을 예방하고 최소화하는 것이 중요하다.

물리치료사는 치료 시 신체접촉을 통한 물리적인 힘을 사용하는 경우가 많아 근골격계에 과도한 부담을 주어 작업관련성 근골격계 통증 발생 위험이 큰 집단 중 하나이다. ${ }^{6}$ 작업관련성 근골격계 질환 에 의한 통증과 불편감은 물리치료사의 업무와 사생활, 그리고 삶의 질에 중요한 영향을 미칠 수 있다. ${ }^{~}$ 물리치료사의 주관적 삶의 질은 환자 치료를 위해 우선되어야 할 과제이기도 하다.9

여러 선행연구에서 물리치료사의 작업관련 근골격계 통증 유병률 이 매우 높다고 보고되고 있으며, $3,8,10$ 우리나라의 경우에도 작업관련 근골격계 통증 유병률이 79.9\%에서 92.4\%까지 보고되고 있다.6.11-13 그 러나 이들 연구는 주로 물리치료사의 직업관련 근골격계 통증의 유 병률과 통증 부위, 근골격계 통증과 관련한 직업의 위험 요인, 대응 
전략에 대한 연구가 대부분이며, 물리치료사의 직무관련 근골격계 통증과삶의 질을 연구한 것은 드물다.14-17

따라서 본 연구에서는 물리치료사를 대상으로 작업관련성 근골 격계 통증의 유병률과 통증 양상을 분석하고 근골격계 통증과 삶의 질의 관련성을 알아보기 위해 실시하였다.

\section{연구방법}

\section{1. 연구 대상 및 시기}

본 연구는 서울과 경기 지역의 종합 병원, 재활 요양 병원, 개인 의원 에 근무하는 물리치료사를 대상으로 설문 조사를 실시하였다. 설문 자료 수집은 2013년 10 월 1 일부터 30 일 사이에 실시하였다.

\section{2. 자료수집 및 표본추출방법}

자료 수집은 구조화된 설문지를 우편과 방문을 통해 연속 모집으로 수집하였다. 연구에 필요한 대상자의 수는 표본수가 총 159 명으로 계 산되었고 설문지 총 200 부를 우편과 방문을 통해 배부하였다.

대상자 표본 선정은 조사시점인 2013년 한국보건산업진흥원의 의 료자원 통계핸드북을 기초로 로 하여 서울과 경기 지역 종합병원 총 113 개 중 4 개, 재활 요양 병원 총 314 개 중 5 개, 개인 의원 총 13,203 개 중 10 개를 임의 편의 추출하여 추출된 기관에서 근무하고 있는 전체 물리치료사를 대상으로 실시하였다. 대상자들은 연구의 목적을 이 해하고 자발적으로 연구에 참여하기로 동의하고 동의서를 작성한 후 설문을 실시하였고 회수한 설문지 170 부 중 응답이 불성실한 설문지 2 부를 제외한 168 부를 최종 분석하였다

\section{3. 측정 도구}

본 연구에 사용한 설문은 자기 기입식 설문지로 대상자의 일반적 특 성과 근골격계 통증, 삶의 질에 대한 질문으로 구성하였다.

\section{1) 일반적 특성}

대상자의 일반적 특성은 성별, 나이, 결혼 여부, 임상경력, 근무처, 1 일 근무시간, 휴식시간으로 구성 하였다.

\section{2) 작업관련 근골격계 통증}

대상자가 자각하고 있는 근골격계 통증을 파악하기 위해 한국 산업 안전공단에서 제시한 근골격계 질환 증상 조사표를 이용하였다. 이 증상 조사표는 미국산업안전보건연구원(NIOSH)에서 정한 근골격 계 증상 기준과 미국 국립 표준과학원(ANSI)에서 만든 증상 조사표 를 근거로 한국 산업안전공단에서 작성한 근골격계 부담 작업유해요 인 조사지침(KOSHA code H-30-2012)의 근골격계 질환 증상조사표이
다. ${ }^{18}$ 대상자가 자각하는 통증 유무와 통증 발생 부위, 통증의 특성을 조사하고 통증 발생 신체부위를 목, 어깨, 팔/손/손목, 허리, 다리/무 릎/발로 분류하여 증상 발병 시기, 지속시간, 증상의 빈도와 원인, 증 상의 강도, 치료 경험에 대해 조사하였다.

통증 정도는 Kim 등 ${ }^{19}$ 이 개발한 통증평정지수(Pain rating score; $\mathrm{PRS)}$ 를 이용하여 측정하였다. 통증평정지수는 임상적으로 중요한 요소인 통증의 강도, 하루 중 빈도, 지속시간, 동작과의 연관성을 모 두 고려하여 통증 지수를 평가할 수 있는 평가 도구이다. 통증 강도는 아프다고 까지는 할 수 없으나 완전한 것은 아니다 라고 느끼는 1단계 에서 당장 무슨 조치를 취하지 않고는 도저히 못 견딜 정도로 아프다 라고 느끼는 10 단계까지 총 10 개로 나뉘어진다. 통증 지속시간은 전 혀 아프지 않다 에서 시간별로 15 분 이내, 15 분-2시간, 2-5시간, 5-10시 간, 10 시간 이상의 6 단계로 나뉘어진다. 통증 빈도는 전혀 아프지 않 다 에서부터 일주일, 하루에 몇 회로 나누어 총 6단계로 나누어져 있 다. 통증 양상은 어떤 동작이나 활동에도 아프지 않다는 0 단계에서 가만히 안정을 취하고 있어도 아프다는 5단계까지 총 6 단계로 구분 되어 있다. 이들 각 영역을 각각 측정하여 다음 식에 따라 통증강도 $\times$ (시간+빈도+동작)으로 통증평정지수를 산출하였다. 척도의 내적 일 치도는 선행 연구에서 크론바하 알파계수(Cronbach's alpha coefficient) 0.97 이었고, ${ }^{19}$ 다른 통증평가도구와 비교하여 타당도와 민감도 가 높은 것으로 나타났다.

\section{3) 삶의 질}

삶의 질은 한국판 세계보건기구 삶의 질 간편형 척도(World Health Organization Quality of Life assessment instrument: WHOQOL-BREF) 를 사용하였다. 한국판 척도는 세계보건기구가 개발한 삶의 질 척도 를 2000년 Min 등20이 한국어로 번역하고 신뢰도와 타당도를 검증하 였다. WHOQOL-BREF는 총 26개 문항으로 되어있으며 전반적인 삶 의 질과 건강에 대한 문항 2 개와 4 개의 하위 영역으로 구성되어있다. 4 개의 하위 영역은 신체적 건강, 심리적 건강, 사회적 관계, 환경 영역 으로 구성되어 있다. 각 문항별 점수는 5점 척도로 전혀 아니다(1점), 약간 그렇다(2점), 그렇다(3점), 많이 그렇다(4점), 매우 많이 그렇다(5 점)으로 채점하였으며 부정 문항의 경우 역산하여 점수를 채점하였 다. 영역별 점수는 신체적 건강이 7문항으로 7-35점, 심리적 건강이 6 문항으로 6-30점, 사회적 관계는 3문항으로 3-15점, 환경 영역은 8문 항으로 8-40점이며 전반적인 삶의 질과 건강에 관한 2 문항을 각각 채 점하여 총점을 계산하였다. 총점은 최저 26점에서 최고 130점 사이로 점수가 높을수록 삶의 질에 대한 긍정적인 반응을 의미한다. 한국판 WHOQOL-BREF 척도의 내적 일치도는 크론바하 알파계수(Cronbach's alpha coefficient) 0.898 이었다. ${ }^{20}$ 


\section{4. 통계 방법 및 자료 분석}

연구 대상자의 일반적 특성과 근골격계 통증 유무는 기술 통계하여 빈도 분석을 실시하였고 일반적 특성에 따른 근골격계 통증 유무의 차이를 비교하기 위해 카이제곱 검정을 실시하였다. 종속변수인 통 증평정지수와 삶의 질 측정 결과의 정규성 검증을 위해 KolmogorovSmirnov 검정한 결과 통증평정지수는 정규분포를 가정하지 않았고 삶의 질은 정규분포를 가정하였다. 따라서 근골격계 통증이 있는 대 상자의 통증 부위와 통증 정도의 특성은 기술 통계하여 빈도와 백분 율로 나타내었으며 복수 응답을 가능하게 하여 총 빈도수가 설문 응 답수보다 많았다. 통증 정도 역시 정규분포를 가정하지 않아 중위수 와 범위로 나타내었다. 통증 유무에 따른 삶의 질은 정규분포하여 차 이를 비교하기 위해 독립표본 $\mathrm{t}$ 검정을 실시하였고 통증과 삶의 질의 관계를 설명하기 위해 Pearson 상관관계 분석을 실시하였다. Pearson 상관계수(correlation coefficient)는 -1.0 에서 +1.0 사이이며 -0.1 에서 +0.1 사이는 거의 무시할 만한 상관성을 나타내며 0.1-0.3은 약한 상관 성을 0.3-0.7은 중간 정도의 상관성을 0.7-1.0은 강한 상관성을 나타낸 다는 일반적인 상관관계 해석 기준을 적용하여 해석하였다. 수집된 자료는 SPSS version 18.0 을 이용하여 분석하였고 통계적 유의수준은 0.05 로 하였다.

\section{결 과}

\section{1. 유병률 및 일반적인 특성별 작업관련 근골격계 통증의 차이}

연구 대상자 중 $76.8 \%$ 는 지난 1년간 작업관련 근골격계 통증을 자각 하였다고 응답하였고 $23.2 \%$ 는 통증이 없다고 응답하였다(Table 1).

연구 대상자의 일반적 특성에 따라 작업관련 근골격계 통증 유무 에 차이를 비교한 결과 성별에 따른 차이가 있었다. 여성 물리치료사 의 경우 작업관련 근골격계 통증이 있다고 대답한 응답자 수가 $85.6 \%$ 였고 남성의 경우 $66.7 \%$ 가 통증이 있다고 응답하여 남성보다는 여성 의 자각 유병률이 더 높았고 통계적으로 유의하였다 $(\mathrm{p}=0.004)$.

근무환경에 따라 작업관련 근골격계 통증 유무에 차이를 비교한 결과 근무경력에 따른 통증 유무의 차이가 있었다. 근무경력이 5년 이상인 경우 $85.3 \%$ 가 작업관련 근골격계 통증이 있다고 응답하였고, 근무경력 5년 이하인 경우 $69.6 \%$ 가 통증이 있다고 응답하여 근무경 력이 많을수록 통증의 자각 유병률이 통계적으로 유의하게 높았다 $(\mathrm{p}=0.017)$.

연구 대상자의 과거 손상 경험과 주관적인 육체부담 정도에 따라 서도 작업관련 근골격계 통증 유무에 차이가 있었는데 과거에 손상 이 있었던 사람이 그렇지 않은 사람에 비해 통증 자각 유병률이 통계

Table 1. Distribution of WMSD by demographic variables and clinical variables

\begin{tabular}{|c|c|c|c|c|c|c|}
\hline & & \multirow{2}{*}{ Total N (\%) } & \multicolumn{2}{|c|}{ WMSD for the past 1 year } & \multirow{2}{*}{$\chi^{2}$} & \multirow{2}{*}{$\mathrm{p}$ value } \\
\hline & & & Yes N (\%) & No N (\%) & & \\
\hline \multicolumn{2}{|l|}{ Overall respondents } & $170(100.0)$ & $129(76.8)$ & $39(23.2)$ & & \\
\hline \multirow[t]{2}{*}{ Gender } & Male & $78(100.0)$ & $52(66.7)$ & $26(33.3)$ & 8.36 & $0.004^{*}$ \\
\hline & Female & $90(100.0)$ & 77 (85.6) & $13(14.4)$ & & \\
\hline \multirow[t]{2}{*}{ Age } & $<30$ & $102(100.0)$ & $77(75.5)$ & $25(24.5)$ & 0.24 & 0.621 \\
\hline & $>30$ & $66(100.0)$ & $52(78.8)$ & $14(21.2)$ & & \\
\hline \multirow[t]{2}{*}{ Marital status } & Married & $53(100.0)$ & $43(81.1)$ & $10(18.9)$ & 0.82 & 0.365 \\
\hline & Not married & $115(100.0)$ & $86(74.8)$ & $29(25.2)$ & & \\
\hline \multirow[t]{3}{*}{ Institution } & General hospital & $57(100.0)$ & $45(78.9)$ & $12(21.1)$ & 2.92 & 0.232 \\
\hline & Rehabilitation hospital & $72(100.0)$ & $51(70.8)$ & $21(29.2)$ & & \\
\hline & Private clinic & $39(100.0)$ & $33(84.6)$ & $6(15.4)$ & & \\
\hline \multirow[t]{2}{*}{ Employment period } & $<5$ & $92(100.0)$ & $64(69.6)$ & $28(30.4)$ & 5.74 & $0.017^{*}$ \\
\hline & $>5$ & $75(100.0)$ & $64(85.3)$ & $11(14.7)$ & & \\
\hline \multirow[t]{2}{*}{ Work hours (daily) } & $<8$ & $137(100.0)$ & $106(77.4)$ & $31(22.6)$ & 0.14 & 0.705 \\
\hline & $>8$ & $31(100.0)$ & $23(74.2)$ & $8(25.8)$ & & \\
\hline \multirow[t]{2}{*}{ Rest in work time } & Yes & $106(100.0)$ & 77 (72.6) & $29(27.4)$ & 2.44 & 0.119 \\
\hline & No & $60(100.0)$ & $50(83.3)$ & $10(16.7)$ & & \\
\hline \multirow[t]{2}{*}{ Leisure activities } & Yes & $82(100.0)$ & $61(74.4)$ & $21(25.6)$ & 0.46 & 0.498 \\
\hline & No & $85(100.0)$ & $68(78.8)$ & $18(21.2)$ & & \\
\hline \multirow[t]{2}{*}{ Injury history } & Yes & $88(100.0)$ & $74(84.1)$ & $14(15.9)$ & 5.53 & $0.019^{*}$ \\
\hline & No & $80(100.0)$ & $55(68.8)$ & 25 (31.3) & & \\
\hline \multirow[t]{2}{*}{ Subjective workload } & Endurable & $80(100.0)$ & $52(65.0)$ & $28(35.0)$ & 11.64 & $0.001^{*}$ \\
\hline & Arduous & $87(100.0)$ & $76(87.4)$ & $11(12.6)$ & & \\
\hline
\end{tabular}

WMSD: Work-related musculoskeletal disorders.

${ }^{*} p<0.05$. 
Table 2. Sites and number of self-reported pain and severity of workrelate musculoskeletal pain

\begin{tabular}{lcc}
\hline Sites of pain & $\mathrm{N}$ & $\%$ \\
\hline Neck & 56 & 33.30 \\
shoulder & 76 & 45.20 \\
Arm/Elbow & 25 & 14.90 \\
Hand/ Wrist & 73 & 43.50 \\
Lower back & 82 & 48.80 \\
Leg/foot & 39 & 23.20 \\
\hline Number of pain site & $\mathrm{N}$ & $\%$ \\
\hline 0 & 39 & 23.20 \\
1 & 45 & 26.80 \\
2 & 25 & 14.90 \\
3 & 15 & 8.90 \\
4 & 21 & 12.50 \\
5 & 11 & 6.50 \\
6 & 12 & 7.10 \\
\hline Pain rating scale & Median & Range \\
\hline Intensity of pain & 42.00 & $3-123$ \\
Duration of pain & 5.00 & $1-10$ \\
Frequency of pain & 3.00 & $1-5$ \\
Pattern of pain & 4.00 & $1-5$ \\
\hline
\end{tabular}

적으로 유의하게 높았고 $(\mathrm{p}=0.019)$, 스스로 업무의 육체부담을 견디 기 힘들다라고 생각하는 사람이 견딜만하다라고 생각하는 사람에 비해 통증 자각 유병률이 더 높았다 $(\mathrm{p}=0.001)$ (Table 1$)$.

\section{2. 작업관련 근골격계 통증 특성과 통증 정도}

연구 대상자 168 명 중 통증이 있다고 응답한 129 명의 작업관련 근골 격계 통증 분포와 정도를 알아본 결과 통증이 있는 부위는 허리 (48.8\%)가 가장 많았고 그 다음이 어깨(45.2\%), 손과 손목(43.5\%), 목, 다 리와 발, 팔 순으로 나타났다(Table 2).

통증이 있는 부위를 다중 응답하도록 하여 통증 부위의 개수를 파 악한 결과 한 부위의 통증을 호소한 경우가 $26.8 \%$ 로 가장 많았고 5,6 개의 여러 부위 통증을 호소한 대상자도 각각 $6.5 \%, 7.1 \%$ 로 나타났다.

작업관련 근골격계 통증의 정도를 파악하기 위해 통증평정지수 를 측정한 결과 총 126 점 중 중위수가 42 점으로 중간 정도의 통증을 느끼고 있는 것으로 나타났다. 세부 측정 항목인 통증의 강도와 통증 지속시간, 통증 빈도, 통증 양상 모두 중위수가 3-5점 사이로 중간 정 도의 통증 정도를 느끼고 있었다(Table 2).

\section{3. 작업관련 근골격계 통증과 삶의 질}

작업관련 근골격계 통증 유무에 따른 삶의 질의 차이를 알아본 결과 통증이 있는 물리치료사의 평균 삶의 질은 82.85 점이었고, 통증이 없 는 물리치료사의 평균 삶의 질은 86.23 점이었다. 통증이 있는 경우 통
Table 3. Quality of life according to work-related musculoskeletal pain

\begin{tabular}{llrrcc}
\hline Domain & \multicolumn{1}{c}{ Group } & $\mathrm{N}$ & Mean \pm SD & $\mathrm{t}$ & $\mathrm{p}$ \\
\hline General health & Non-pain group & 39 & $6.92 \pm 0.98$ & 3.81 & $<0.001^{*}$ \\
& Pain group & 129 & $6.18 \pm 1.31$ & & \\
Physical & Non-pain group & 39 & $25.15 \pm 3.89$ & 2.77 & $0.006 *$ \\
& Pain group & 129 & $23.08 \pm 4.17$ & & \\
Psychological & Non-pain group & 39 & $19.79 \pm 3.21$ & 0.63 & 0.531 \\
& Pain group & 129 & $19.39 \pm 3.65$ & & \\
Social & Non-pain group & 39 & $9.72 \pm 1.79$ & -1.33 & 0.184 \\
& Pain group & 129 & $10.13 \pm 1.67$ & & \\
Environmental & Non-pain group & 39 & $24.64 \pm 4.10$ & 0.68 & 0.499 \\
& Pain group & 129 & $24.08 \pm 4.67$ & & \\
QOL total & Non-pain group & 39 & $86.23 \pm 11.25$ & 1.45 & 0.148 \\
& Pain group & 129 & $82.85 \pm 13.11$ & &
\end{tabular}

SD: Standard deviation.

${ }^{*} \mathrm{p}<0.05$.

Table 4. The Spearman correlation coefficients between variables of pain rating scale and QOL

\begin{tabular}{|c|c|c|c|c|c|c|}
\hline & $\mathrm{QOL}$ & $\begin{array}{c}\text { General } \\
\text { health }\end{array}$ & Physical & Psychologicalr & - Social & Environmenta \\
\hline PRS & $-0.28^{*}$ & $-0.34^{*}$ & $-0.41^{*}$ & -0.15 & -0.06 & $-0.17^{*}$ \\
\hline $\begin{array}{l}\text { Intensity } \\
\text { of pain }\end{array}$ & $-0.25^{*}$ & $-0.33^{*}$ & $-0.37^{*}$ & $-0.15^{*}$ & 0.01 & -0.15 \\
\hline $\begin{array}{l}\text { Duration } \\
\text { of pain }\end{array}$ & $-0.27^{*}$ & $-0.34^{*}$ & $-0.39^{*}$ & -0.14 & -0.05 & $-0.19^{*}$ \\
\hline $\begin{array}{l}\text { Frequency } \\
\text { of pain }\end{array}$ & $-0.18^{*}$ & $-0.24^{*}$ & $-0.25^{*}$ & -0.09 & -0.02 & -0.12 \\
\hline $\begin{array}{l}\text { Pattern } \\
\text { of pain }\end{array}$ & $-0.15^{*}$ & $-0.26^{*}$ & $-0.26^{*}$ & -0.04 & -0.01 & -0.08 \\
\hline
\end{tabular}

PRS: Pain rating scale, QOL: Quality of life. ${ }^{*} p<0.05$.

증이 없는 경우 보다 평균 삶의 질이 조금 더 낮았으나 이러한 차이는 통계적으로 유의하지 않았다 $(\mathrm{p}=0.148)$. 그러나 삶의 질 척도의 하위 영역인 전반적인 삶의 질과 건강에 대한 항목과 신체적인 건강에 대한 항목에서 통증이 있는 물리치료사들의 삶의 질이 통증이 없는 물리 치료사보다 통계적으로 유의하게 낮았다 $(\mathrm{p}<0.001, \mathrm{p}=0.006$ ) (Table 3).

작업관련 근골격계 통증 정도를 나타낸 통증평정지수와 삶의 질 관련성을 살펴본 결과 통증 정도와 삶의 질은 -0.15--0.28 사이의 낮 은 음의 상관관계를 나타내어 통증을 자각하는 정도가 심할수록 삶 의 질이 낮아지는 것으로 나타났으며 통계적으로 유의한 의미가 있 었다 $(\mathrm{p}<0.05)$. 또한 삶의 질 하위 영역 중 전반적인 삶의 질과 신체 영 역이 통증평정지수와 -0.24 에서 -0.41 사이의 음의 상관관계를 나타 내었다(Table 4).

\section{고 찰}

물리치료사는 통증을 가지고 있는 환자들을 치료하고, 통증을 감소 
시키고 그로 인한 기능 장애를 개선하기 위해 운동 프로그램을 개발 하고 교육하는 전문인들이다. 역설적으로 전문가인 물리치료사들에 게 직업관련 근골격계 통증 유병률이 높고 그로 인한 삶의 질이 낮다 는 것은 관심을 가지고 생각해 보아야 할 과제이다.

본 연구에서는 육체적 업무 부담이 높은 것으로 알려진 물리치료 사의 작업관련성 근골격계 통증의 유병률과 통증 양상을 분석하고 근골격계 통증과 삶의 질의 관련성을 알아보았다.

그 결과 연구 대상자 중 $76.8 \%$ 가 지난 1년간 작업관련성 근골격계 통증을 자각하였다고 응답하였다. 우리나라의 선행 연구들과 비교 하면 작업관련성 근골격계 통증 유병률은 Bae 등6 이 보고한 79.9\%, Yong 등 ${ }^{11}$ 이 보고한 $80.1 \%$ 와 유사하였고 Chung 등 ${ }^{3}$ 이 보고한 $92.4 \%$ 보 다는 낮은 유병률을 나타내었다. 국외 연구들과 비교하면 호주 $91 \%,{ }^{15}$ 영국 $68 \%,{ }^{21}$ 나이지리아 $91.3 \%,{ }^{17}$ 말레이지아 $71.6 \%,{ }^{3}$ 이스라엘 $83 \%,{ }^{10}$ 쿠 웨이트 $47.6 \% 22$ 의 다양한 유병률을 보고하고 있다. 이렇게 나라마다 다양한 유병률을 나타내지만 공통적으로 허리의 유병률이 가장 높 았고 어깨, 목, 손목 등의 상지가 다리, 무릎, 발 등의 하지에 비해 높은 유병률을 나타내었다. 본 연구에서도 통증이 있는 부위의 분포는 허 리가 $48.8 \%$ 로 가장 높게 나타났고 어깨(45.2\%), 손과 손목(43.5\%), 목 (33.3\%), 다리와 발(23.2\%), 팔(14.9\%) 순으로 나타나 대부분의 선행 연 구들과 유사한 결과를 나타내었다. 통증 발생 위험 요인을 함께 조사 한 선행 연구에서 같은 작업을 반복적으로 하거나 부적절한 방법으 로 환자나 무거운 물건을 이동시키는 동작, 손목을 과도하게 구부리 거나 힘을 주는 작업을 많이 하고 오랜 시간 같은 자세 (특히 선 자세) 로 업무를 수행하는 것이 높은 원인이었던 것으로 나타나 본 연구의 통증 발생 부위의 순서를 뒷받침한다 할 수 있다.12-13

대상자들의 일반적인 특성, 근무환경과 관련한 특성에 따라 통증 유무를 비교한 결과 성별과 근무 경력에 따라 통증 자각에 차이가 있 었다. 여성일수록 근무경력이 5년 이상 일 때 통증 자각율이 높았고, 과거 손상이 있었거나 업무의 육체적 부담을 견디기 힘들다고 느낄 수록 통증 자각율이 높았다. 이러한 결과는 여성이면서 BMI가 25 이 상일 때, 임상 경력이 작을수록 통증 자각율이 높다고 보고한 Nordin 등의 연구와 가장 유사하였고 ${ }^{3}$ 우리나라 물리치료사를 대상으로 가 장 최근에 발표한 Chung 등13의 연구와도 일치하였다. 일반적으로 여 성은 남자보다는 신체적으로 약하고 환자를 들거나 이동시키는 동 안 불리한 점이 많다. 또한 여성은 임신과 관련하여 자세나 관절 구조 의 약화 등이 나타나 허리 부위에 더 많은 통증 요인을 일으키기도 한다. 이러한 이유로 본 연구에서도 남성보다는 여성 물리치료사의 통증 유병률이 유의하게 높았던 것으로 사료된다. 스웨덴의 한 연구 에서는 임상경력 15 년 이상의 여성 물리치료사 203명을 대상으로 근 골격계 통증을 조사한 결과 한 부위 이상의 통증이 있는 대상자가 $53.5 \%$ 였으며 손과 손목, 허리의 통증이 많이 나타나 본 연구의 결과
와 유사하였다고 ${ }^{23}$ 물리치료사들의 작업관련 육체부담이 높은 것으 로 나타난 Lee 등 ${ }^{24}$ 의 연구와도 유사하였다.

본 연구에서 나타난 작업관련성 근골격계 통증의 특성은 대다수 의 대상자들이 1 개 이상의 통증 부위를 호소하였고 5,6 개의 여러 부 위 통증을 호소한 대상자도 있었다. 또한 통증 정도를 파악한 결과 통증의 강도나 지속시간, 통증 빈도, 통증 양상 모두 중등도 이상의 통증 정도를 나타내었다. 한 연구에서는 보건의료 분야 10 개 직군의 작업관련 근골격계 통증 유병률을 조사한 결과 10 개 직군의 기준이 되는 치과의사와 비교하였을 때 물리치료사들의 근골격계 질환 위 험율이 8 개 질환에서 모두 가장 높았고 다른 직군에 비해 근골격계 질환 위험율이 가장 높았다. ${ }^{25}$ 이와 같은 결과는 본 연구의 결과를 뒷 받침하며 물리치료사가 업무와 관련한 근골격계 질환 유병률이 다 른 직업군에 비해 높고 위험 요인이 많으므로 근골격계 질환 예방을 위한 프로그램이 필요하다는 것을 강조하고 있다.

근골격계 질환의 증가는 노동자의 삶의 질을 저하시킬 수 있으며 이는 곧 근골격계 질환의 예방 및 치료를 통해 노동자의 건강 관련한 삶의 질이 향상될 수 있음을 의미한다. 본 연구에서는 또 하나 중요 한 결과로 물리치료사의 작업관련 근골격계 통증과 관련한 삶의 질 을 측정하였다. 그 결과 통증이 있는 물리치료사의 전반적인 삶의 질 과 신체적인 삶의 질 영역이 통증이 없는 물리치료사에 비해 낮았다. 또한 물리치료사가 통증을 자각하는 통증 정도와 삶의 질의 상관관 계를 분석한 결과 통증 정도와 삶의 질은 약한 음의 상관관계를 나타 내어 $(\mathrm{r}=-0.28)$ 통증을 자각하는 정도가 심할수록 삶의 질이 낮아진 다는 결과를 나타내었다. 본 연구와 같이 물리치료사의 직무관련성 근골격계 통증과 삶의 질을 연구한 $\mathrm{Bae}$ 등 ${ }^{6}$ 의 연구는 본 연구와 같은 측정 척도를 사용하여 통증 정도와 삶의 질이 -0.31 의 음의 상관관계 를 나타내었고 본 연구의 결과와 유사하였다. 제조업 노동자들의 직 업관련 근골격계 통증과 삶의 질 관련성을 연구한 국내 연구의 결과 작업관련 근골격계 증상이 있는 경우 삶의 질 척도인 SF-36의 영역별 점수가 낮아졌다는 결과와도 유사하였다. ${ }^{2}$ 하위 영역들간의 상관 관 계 역시 본 연구에서는 $\mathrm{r}=-0.15--0.41$ 의 약한 상관관계와 중간정도의 상관관계를 나타내었고 Bae 등의 연구에서도 $r=0.12-0.33$ 의 약한 음 의 상관관계를 나타내었다. 이와 같이 두 연구에서 통증 정도와 삶의 질 사이의 관련성이 낮게 나타난 이유는 연구대상자들이 느끼는 통 증이 질환으로 확진된 것이 아니라 자각 정도일 뿐이며 통증으로 인 한 신체적 장애가 없는 상태였기 때문일 것으로 사료된다. 삶의 질에 영향을 미치는 요인은 통증만이 아닌 우울이나 자기효능감과 같은 다양한 심리, 사회적 요인들이 영향을 미치는 것으로 알려져 있다. ${ }^{26}$ 따라서 본 연구의 결과를 바탕으로 이후 물리치료사의 근골격계 통 증의 다양한 특성과 이것이 삶의 질에 미치는 영향에 대한 후속 연구 가 필요하다고 사료된다. 
물리치료사의 작업관련 근골격계 통증의 유병률과 통증 유발 위 험 요인에 관한 연구는 많은 나라들에서 이루어져있다. 우리나라의 경우에도 물리치료사의 작업관련 근골격계 통증의 유병률이 높고 작업과 관련한 위험 요인과 대처 방안에 대한 연구들이 이루어져 있 으며 이를 직무관련 스트레스나 직무만족도와 관련하여 연구가 많 이 이루어져 있다.11-12 그러나 아쉽게도 물리치료사의 직무관련성 근 골격계 통증과 삶의 질을 연구한 국외 연구는 거의 없으며 국내 연구 도 하나에 불과하여 다양한 비교와 해석이 불가능하였다. 본 연구는 물리치료사의 작업관련 근골격계 통증의 분포와 통증 정도, 통증에 영향을 미치는 요인, 삶의 질 사이의 관련성을 통해 물리치료사들이 근골격계 통증을 관리하는데 기초 자료로 제공하고자 하였다. 앞으 로 물리치료사의 직업관련 근골격계 질환과 발병 위험요인, 직무관 련 스트레스와 삶의 질에 관한 다양한 연구가 이루어져야 할 것으로 사료된다. 뿐만 아니라 물리치료사의 근무 환경에서 근골격계 질환 개선을 위한 교육과 운동 프로그램 개발, 근무 환경 개선 작업 등에 기초 자료로 사용된다면 물리치료사의 삶의 질을 향상시키고 이어 져 환자 관리에도 도움이 될 것으로 사료된다.

본 연구의 제한점은 설문 대상을 전국 단위로 표집하지 못했고 서 울 경기 지역의 물리치료사로제한하여 전체 물리치료사의 작업관련 근골격계 통증 유병률로 일반화할 수 없다는 것이며 물리치료사의 작업관련 근골격계 통증 위험 요인에 대한 질문을 따로 하지 않았고, 통증 자각에 작업 외 다른 요인의 영향을 구분할 수 없다는 것이다. 이 러한 제한점들을 보완하여 향후 더 많은 연구가 이루어졌으면 한다.

\section{ACKNOWLEDGEMENTS}

This study was financially supported by the research fund of Dongnam Health University in 2010.

\section{REFERENCES}

1. Punnett L, Wegman DH. Work-related musculoskeletal disorders: the epidemiologic evidence and the debate. J Electromyogr Kinesiol. 2004; 14(1):13-23.

2. Bahk JW, Roh S. Relationship between self-reported symptoms of workrelated musculoskeletal disorders and health related quality of life. Ann Occup Environ Med. 2007;19(2):156-63.

3. Nordin NA, Leonard JH, Thye NC. Work-related injuries among physiotherapists in public hospitals: a Southeast Asian picture . Clinics. 2011; 66(3):373-8.

4. Jeong BY. Ergonomics' role for preventing musculoskeletal disorders. J Ergon Soc Korea. 2010;29(4):393-404.

5. Kim JH, Kim HJ. A study on the musculoskeletal pain experience of dental hygienist's treatment posture. J Dent Hyg Sci. 2009;9:413-8.
6. Bae YH, Lee JH, Yoo HJ et al. Associations between work-Related musculoskeletal pain, quality of life and presenteeism in physical therapists. J Korean Soc Occup Environ Hyg. 2012;22(1):61-72.

7. Kim MA, Seo HJ. Dental Hygienists Work on the Impact of Factors Associated with Musculoskeletal Pain. J Dent Hyg Sci. 2012;12(6):558-65.

8. Alperovitch-Najenson D, Treger I, Kalichman L. Physical therapists versus nurses in a rehabilitation hospital: comparing prevalence of work-related musculoskeletal complaints and working conditions. Arch Environ Occup Health. 2014;69(1):33-9.

9. Koo MO, Lee IH. A study on the relationship between subjective quality of life and job stress among physical and occupational therapists. J Kor Phys Ther. 2010;22(2):69-76.

10. Rozenfeld V, Ribak J, Danziger J et al. Prevalence, risk factors and preventive strategies in work-related musculoskeletal disorders among Israeli physical therapists. Physiother Res Int. 2010;15(3):176-84.

11. Yong JH, Yi CH, Kwon OY et al. Work-related musculoskeletal pain and job stress in physical therapists. Phys Ther Korea. 2010;17(1):53-61.

12. Lee KS, LeeWH, Yun MJ. Relationship between musculoskeletal pain and job satisfaction of the physical therapists in elderly care facilities. The Korean Journal of Health Service Management. 2012;6(4):49-60.

13. Chung SH, Her JG, Ko T et al. Work-related musculoskeletal disorders among korean physical therapists. J Phys Ther Sci. 2013;25(1):55-9.

14. Bork BE, Cook TM, Rosecrance JC et al. Work-related musculoskeletal disorders among physical therapists. Phys Ther. 1996;76(8):827-35.

15. Cromie JE, Robertson VJ, Best MO. Work-related musculoskeletal disorders in physical therapists: prevalence, severity, risks, and responses. Phys Ther. 2000;80(4):336-51.

16. Salik Y, Ozcan A. Work-related musculoskeletal disorders: a survey of physical therapists in Izmir-Turkey. BMC Musculoskelet Disord. 2004; 18;5:27.

17. Adegoke BO, Akodu AK, Oyeyemi AL. Work-related musculoskeletal disorders among Nigerian physiotherapists. BMC Musculoskelet Disord. $2008 ; 18 ; 9: 112$.

18. Korea Occupational Safety \& Health Agency(KOSHA). CODE H-92012. Retrieved August 1, 2013.

19. Kim C, Kim C, Chun SI. Clinical Value of a New Self Assessment Method of Pain. Ann Rehabil Med. 1998;22(2):305-11.

20. Min SK, Kim KI, Suh SY et al. Development of Korean Version of WHO Quality of Life Scale Abbreviated Version (WHOQOL-BREF). J Korean Neuropsychiatr Assoc. 2000; 39(1):78-88.

21. Glover W, McGregor A, Sullivan et al. Work-related musculoskeletal disorders affecting members of the Chartered Society of Physiotherapy. Physiotherapy. 2005;91(3):138-147.

22. Alrowayeh HN, Alshatti TA, Aljadi SH et al. Prevalence, characteristics, and impacts of work-related musculoskeletal disorders: a survey among physical therapists in the State of Kuwait. BMC Musculoskelet Disord. 2010;11;11:116.

23. Grooten WJ, Wernstedt P, Campo M. Work-related musculoskeletal disorders in female Swedish physical therapists with more than 15 years of job experience: prevalence and associations with work exposures. Physiother Theory Pract. 2011;27(3):213-22.

24. Lee JH, Choi YC, Kim JS. Work-related musculoskeletal pain and workload evaluation of physical therapists: focused on neurological injury treatment of adults. Phys Ther Korea. 2012;19(2):69-79. 
25. Wang SY, Liu LC, Lu MC et al. Comparisons of musculoskeletal disorders among ten different medical professions in Taiwan: a nationwide, population-based study. PLoS One. 2015; 10;10(4):e0123750.

26. Ko DS, Lee DJ, Ko TS. Changes in job stress, self-efficacy, depression and health-related quality of life according to the degree of musculoskeletal symptoms for white-collar workers. Journal of the Korea Academia-Industrial cooperation Society. 2013;14(6):2935-44. 